\title{
Selective Inhibition of KCC2 Leads to Hyperexcitability and Epileptiform Discharges in Hippocampal Slices and In Vivo
}

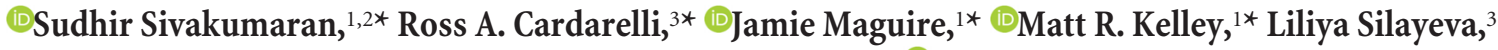 \\ Danielle H. Morrow, ${ }^{1}$ Jayanta Mukherjee, ${ }^{3}$ Yvonne E. Moore, ${ }^{1}$ ORobert J. Mather, ${ }^{3,4}$ Mark E. Duggan, ${ }^{3,4}$ \\ Nicholas J. Brandon, ${ }^{3,4}$ John Dunlop, ${ }^{3,4}$ @Stephen Zicha, ${ }^{3,4}$ Stephen J. Moss, ${ }^{1,3,5}$ and Tarek Z. Deeb ${ }^{3}$ \\ ${ }^{1}$ Department of Neuroscience, Tufts University School of Medicine, Boston, Massachusetts 02111, ${ }^{2}$ Department of Biosciences, University of Helsinki, \\ 00014 Helsinki, Finland, ${ }^{3}$ AstraZeneca Tufts Laboratory for Basic and Translational Neuroscience, Boston, Massachusetts 02111, ${ }^{4}$ AstraZeneca \\ Neuroscience iMED, Cambridge, Massachusetts 02139, and ${ }^{5}$ Department of Neuroscience, Physiology and Pharmacology, University College, London, \\ WC1E 6BT, United Kingdom
}

$\mathrm{GABA}_{\mathrm{A}}$ receptors form $\mathrm{Cl}^{-}$permeable channels that mediate the majority of fast synaptic inhibition in the brain. The $\mathrm{K}^{+} / \mathrm{Cl}^{-}$cotransporter KCC2 is the main mechanism by which neurons establish low intracellular $\mathrm{Cl}^{-}$levels, which is thought to enable GABAergic inhibitory control of neuronal activity. However, the widely used KCC2 inhibitor furosemide is nonselective with antiseizure efficacy in slices and in vivo, leading to a conflicting scheme of how KCC2 influences GABAergic control of neuronal synchronization. Here we used the selective KCC2 inhibitor VU0463271 [ $\mathrm{N}$-cyclopropyl- $\mathrm{N}$-(4-methyl-2-thiazolyl)-2-[(6-phenyl-3-pyridazinyl)thio]acetamide] to investigate the influence of KCC2 function. Application of VU0463271 caused a reversible depolarizing shift in $E_{\mathrm{GABA}}$ values and increased spiking of cultured hippocampal neurons. Application of VU0463271 to mouse hippocampal slices under low- $\mathrm{Mg}^{2+}$ conditions induced unremitting recurrent epileptiform discharges. Finally, microinfusion of VU0463271 alone directly into the mouse dorsal hippocampus rapidly caused epileptiform discharges. Our findings indicated that KCC2 function was a critical inhibitory factor ex vivo and in vivo.

Key words: chloride; GABAA; KCC2; seizures; slices; VU0463271

\section{Introduction}

Neuronal activity patterns in the CNS are shaped by inhibitory synaptic signaling (Freund and Buzsáki, 1996; Isaacson and Scanziani, 2011). Because of the excitatory effects of $\mathrm{Na}^{+}$currents and the lack of neurotransmitter-gated selectively permeable $\mathrm{K}^{+}$ channels (Alexander et al., 2011), fast synaptic inhibition in the mammalian CNS is mediated by the anion permeable $\mathrm{GABA}_{\mathrm{A}}$ and glycine ionotropic receptors. Synaptic GABA $\mathrm{A}_{\mathrm{A}}$ currents mediate shunting and hyperpolarizing inhibition. Although both forms of inhibition are affected by the $\left[\mathrm{Cl}^{-}\right]_{\mathrm{i}}$, sustained hyperpolarizing $\mathrm{GABA}_{\mathrm{A}}$-mediated currents are only possible if neurons have a mechanism that persistently extrudes $\mathrm{Cl}^{-}$. This persistent isotonically active $\mathrm{Cl}^{-}$extrusion mechanism was ascribed to KCC2 after it was tested in vitro (Payne, 1997). KCC2

Received Dec. 22, 2014; revised April 7, 2015; accepted April 20, 2015.

Author contributions: S.S., J.Ma., S.Z., S.J.M., and T.Z.D. designed research; S.S., R.A.C., J.Ma., M.R.K., J.Mu., Y.E.M., and T.Z.D. performed research; L.S., D.H.M., R.J.M., M.E.D., N.J.B., J.D., and S.Z. contributed unpublished reagents/analytic tools; S.S., R.A.C., J.Ma., M.R.K., and T.Z.D. analyzed data; N.J.B., J.D., S.Z., S.J.M., and T.Z.D. wrote the paper.

This work was supported by the Academy of Finland (S.S.), Simons Foundation Grant 206026 (S.J.M.), National Institutes of Health/National Institute of Neurological Disorders and Stroke Grants, NS051195, NS056359, NS081735, NS087662 (S.J.M.), and NS073574 (J.Ma.), and funding from AstraZeneca (S.J.M.).

*S.S., R.A.C., J.Ma., and M.R.K. contributed equally to this work.

The authors declare no competing financial interests.

Correspondence should be addressed to Drs. TarekZ. Deeb and Stephen J. Moss, AstraZeneca Tufts Laboratory for Basic and Translational Neuroscience, Department of Neuroscience, Tufts Medical School, 136 Harrison Avenue, Boston, MA 02111. E-mail: Tarek.Deeb@tufts.edu, Stephen.Moss@tufts.edu.

DOI:10.1523/JNEUROSCI.5205-14.2015

Copyright $\odot 2015$ the authors $\quad 0270-6474 / 15 / 358291-06 \$ 15.00 / 0$ exhibits the predicted effects on $\mathrm{Cl}^{-}$homeostasis in neurons (Rivera et al., 1999) and a temporal expression pattern that matches the postnatal development of hyperpolarizing IPSPs in the hippocampus (Schwartzkroin, 1981; Ben-Ari et al., 1989).

Genetic knock-out of KCC2 expression is lethal at birth (Hübner et al., 2001), and genetic knock-out of the KCC2b isoform leads to spontaneous seizures and death 2-3 weeks postnatally (Woo et al., 2002; Uvarov et al., 2007). However, KCC2 exhibits several transport-independent properties at excitatory synapses: (1) it binds scaffolding proteins within dendritic spines (Li et al., 2007); (2) it affects dendritic spine morphology (Fiumelli et al., 2013); (3) it influences the lateral membrane diffusion of AMPA receptors (Gauvain et al., 2011); and (4) it forms complexes with kainate receptors (Mahadevan et al., 2014). Because of these transporter-independent properties, it is unclear whether the vital and anticonvulsant roles of KCC2 are caused by its $\mathrm{K}^{+} / \mathrm{Cl}^{-}$ cotransport function.

Moreover, pharmacological inhibition of KCC2 has yielded contradictory results. In cultured hippocampal neurons, the nonselective KCC2 inhibitor furosemide positively shifts the reversal potential of $\mathrm{GABA}_{\mathrm{A}}$-mediated currents $\left(E_{\mathrm{GABA}}\right)$ and increases spontaneous firing rates (Jarolimek et al., 1996; Deeb et al., 2013). In contrast, furosemide applied to hippocampal slices suppresses synchronized activity in several models of seizures, including the low- $\mathrm{Mg}^{2+}$ model (Hochman et al., 1995; Gutschmidt et al., 1999). Furosemide also exhibits antiseizure actions in rodents (Hochman et al., 1995) and humans (Ahmad et al., 
1976; Haglund and Hochman, 2005). Therefore, we sought to clarify these discrepancies by using the selective KCC2 inhibitor VU0463271 [N-cyclopropyl- $N$ (4-methyl-2-thiazolyl)-2-[(6-phenyl-3pyridazinyl)thio]acetamide (Delpire et al., 2012)] to test whether it would increase network activity in cultured neurons, aggravate low- $\mathrm{Mg}^{2+}$-induced epileptiform discharges in hippocampal slices, and provoke seizures in awake behaving mice.

\section{Materials and Methods}

Animals. Cultured neurons were obtained from E18 embryos from Sprague Dawley rats (Charles River). C57BL/6 male mice aged 3-5 weeks were used for slice recordings, and 10- to 12-week-old mice were used for EEG experiments. All animal procedures were performed in accordance with the National Institutes of Health and approved by the Institutional Animal Care and Use Committee of Tufts University.

Cell culture. Hippocampal neurons were plated at 250,000 cells per dish and maintained in Neurobasal media containing B27 (2\%), glucose $(0.6 \%)$, Glutamax $(1 \%)$, and penicillin/streptomycin (1\%), and grown for 18-21 d before experimentation. HEK cells were grown in DMEM containing 10\% FBS and 1\% penicillin/streptomycin. HEK cells were transfected with cDNA encoding human KCC2, rat glycine $\alpha 1$ subunit, and eGFP using Lipofectamine and were grown for $48 \mathrm{~h}$ before experimentation. Cell culture materials were purchased from Invitrogen.

Compounds. VU0463271 was generously provided by Craig Lindsley (Vanderbilt University, Nashville, TN) and dissolved in DMSO at a concentration of $10 \mathrm{~mm}$. The selectivity of VU0463271 against a broad range of targets was tested in binding and functional assay panels (Cerep). The assay methodology can be found online at www.cerep.fr. We used gramicidin (50 $\mu \mathrm{g} / \mathrm{ml}$; Sigma) for perforated patch experiments. Glycine (100 mM), muscimol $(50 \mathrm{~mm})$, and TTX (1 $\mathrm{mm})$ were dissolved in deionized $\mathrm{H}_{2} \mathrm{O}$ and purchased from Tocris Bioscience.

Electrophysiology. Neuron culture recordings were performed at $34^{\circ} \mathrm{C}$, and HEK cells were recorded at room temperature in the bath saline. For perforated patch experiments, pipettes contained saline (in $\mathrm{mm}$ ): $140 \mathrm{KCl}$ and 10 HEPES, pH 7.4 KOH. For whole-cell experiments, pipettes contained saline (in $\mathrm{mM}$ ): 130 K-gluconate, $10 \mathrm{KCl}, 0.1 \mathrm{CaCl}_{2}, 2 \mathrm{Mg}$-ATP, 1.1 EGTA, and 10 HEPES, pH 7.4 KOH. Bath saline contained the following (in $\mathrm{mm}$ ): 140 $\mathrm{NaCl}, 2.5 \mathrm{KCl}, 2.5 \mathrm{CaCl}_{2}, 1.2 \mathrm{MgCl}_{2}, 10$ HEPES, and 11 glucose, pH 7.4 NaOH. We performed an equimolar substitution of $\mathrm{NaCl}$ by $\mathrm{KCl}$ for the $10 \mathrm{~mm}\left[\mathrm{~K}^{+}\right]_{\mathrm{o}}$ experiments. All solutions were applied onto cells using a threebarrelled $700 \mu \mathrm{m}$ pipe positioned just above the cell (Warner Instruments). We used $20 \mathrm{mV}$ voltage-ramp protocols over $1 \mathrm{~s}$ periods to determine the reversal potentials of the leak-
$A$

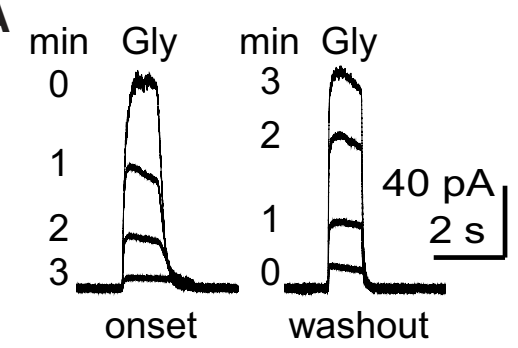

B
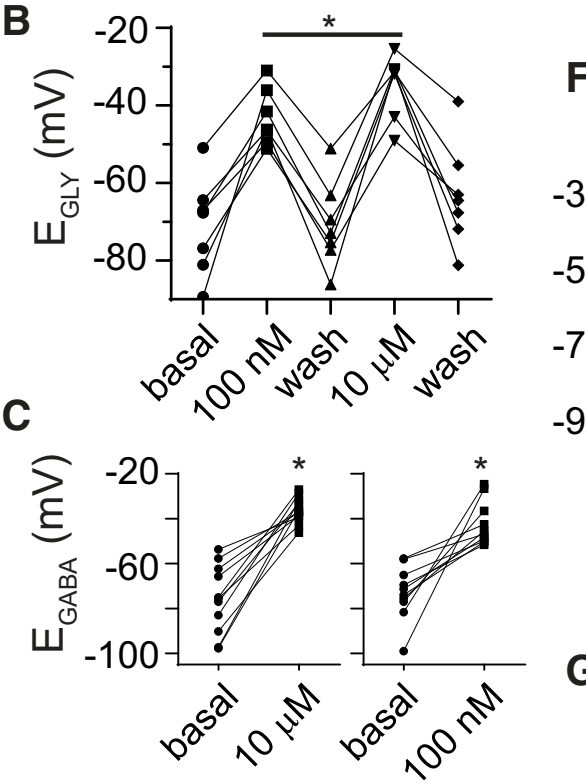

D
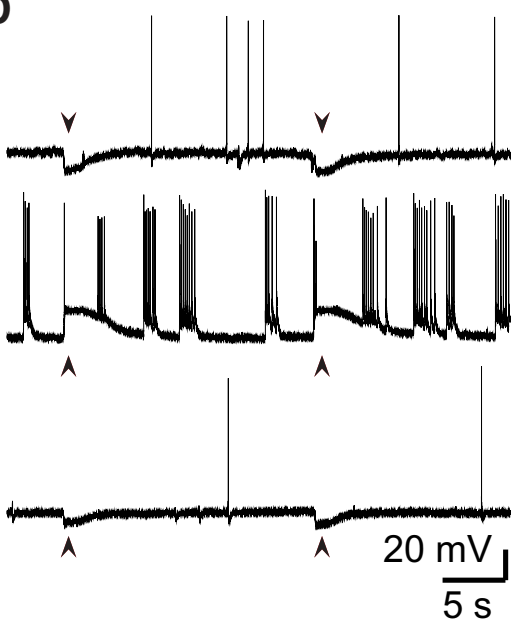

$\mathbf{E}$

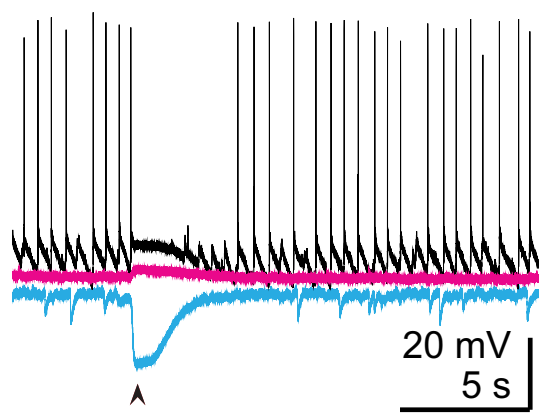

$\mathbf{F}$
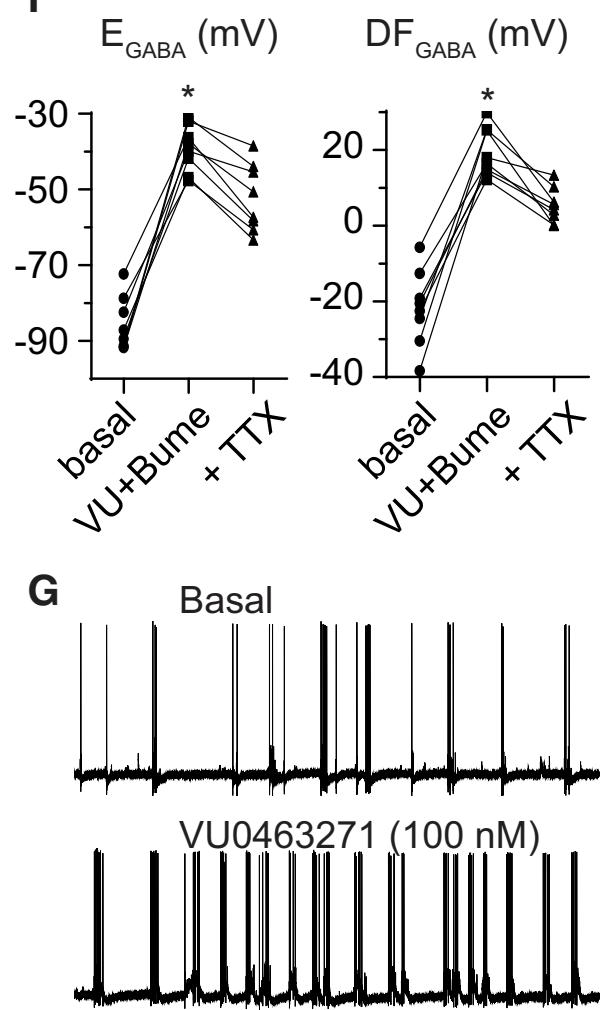

VU0463271 (10 $\mu \mathrm{M})$

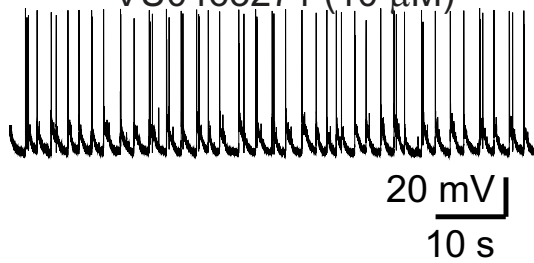

Figure 1. VU0463271 caused a depolarizing shift in $E_{\text {Gly }}$ values and $E_{\text {GABA }}$ values. A, Glycine-activated currents in KCC2expressing HEK cells decreased during onset of $10 \mu \mathrm{m}$ VU0463271 (left) and then recovered during washout (right). The time of each glycine pulse is indicated to the left of each trace, and the holding potential was $-30 \mathrm{mV}$. $\boldsymbol{B}$, Graph of $E_{\text {Gly }}$ values of KCC2-expressing HEK cells before, during, and after VU0463271 exposure at different concentrations. Lines connect the values obtained for each cell. $C$, Graph of $E_{\text {GABA }}$ values of cultured neurons before and during VU0463271 exposure at the indicated concentrations. Lines connect the values obtained for each cell. $\boldsymbol{D}$, Traces show the shift in polarity of muscimol responses (arrowheads) under basal conditions (top trace), during exposure to VU0463271 (10 $\mu \mathrm{m}$; middle trace), and after washout (bottom trace). $\boldsymbol{E}$, Traces of neuronal activity under basal conditions (blue), 4 min after onset of VU0463271 plus bumetanide (black), and 4 min after onset of VU0463271 plus bumetanide plus TTX (red). Note the reduction in muscimol amplitude (arrow-

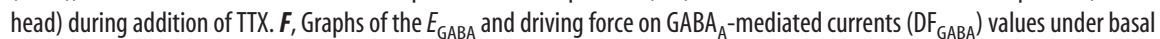
conditions, after a 4 min exposure to VU0463271 (VU) plus bumetanide (Bume), and after a 4 min exposure to VU0463271 plus bumetanide plus TTX. G, Traces illustrate the increased spontaneous firing rates after exposure to VU0463271 at $100 \mathrm{~nm}$ (middle) and $10 \mu \mathrm{m}$ (bottom). ${ }^{*}$ Indicates statistical significance of $p<0.05$ (see text for specific values). 


\section{Table 1. Off-target hits of VU0463271}

\begin{tabular}{|c|c|}
\hline Targets & $\mathrm{IC}_{50}(\mu \mathrm{m})$ \\
\hline \multicolumn{2}{|l|}{ Radiometric binding assays } \\
\hline TSP0, rat, heart [3H]PK 11195 & 0.204 \\
\hline $\mathrm{NK}_{1}$, human, membrane $\left[{ }^{125} 1\right] \mathrm{BH}-\mathrm{SP}$ & 4.975 \\
\hline $5-\mathrm{HT}_{1 \mathrm{~A}}$, human, membrane $\left[{ }^{3} \mathrm{H}\right] 8-\mathrm{OH}-\mathrm{DPAT}$ & 5.516 \\
\hline Opioid receptor $\kappa 1$, rat, membrane $\left[{ }^{3} \mathrm{H}\right] \mathrm{U} 69593$ & 6.016 \\
\hline mAChR1, human, membrane $\left[{ }^{3} \mathrm{H}\right]$ pirenzepine & 7.089 \\
\hline Adenosine A2a, human, membrane $\left[{ }^{3} \mathrm{H}\right] \mathrm{CGS} 21680$ & 39.38 \\
\hline Adenosine ENT, guinea pig, crude extract $\left[{ }^{3} \mathrm{H}\right] \mathrm{NBTI}$ & 40.72 \\
\hline Adrenergic $\beta 2$, human, membrane $\left[{ }^{3} \mathrm{H}\right](-) \mathrm{CGP} 12177$ & 49.56 \\
\hline $5-\mathrm{HT}_{2 \mathrm{C}}$, human, membrane $\left[{ }^{3} \mathrm{H}\right]$ mesulergine & 53.98 \\
\hline $\mathrm{SST}_{4}$, human, membrane $\left[{ }^{125} \mathrm{I}\right] \mathrm{T} y \mathrm{r} 11$-somatostatin- 14 & 60.61 \\
\hline$C a_{V}, L$ type, $\alpha 1^{\#}$, rat, crude extract $\left[{ }^{3} \mathrm{H}\right]$ diltiazem & 94.97 \\
\hline PPAR $\gamma$, human, membrane $\left[{ }^{3} \mathrm{H}\right]$ rosiglitazone & 98.46 \\
\hline \multicolumn{2}{|l|}{ Functional assays } \\
\hline $\begin{array}{l}\text { Adrenergic } \alpha 1 B \text {, human, } \text { CH0 epinephrine cAMP time } \\
\text { resolved fluorescence }\end{array}$ & 0.3647 \\
\hline $\begin{array}{l}\mathrm{NK}_{1} \text {, human, U-373 MG }\left[\operatorname{Sar9Met}\left(\mathrm{O}_{2}\right) 11\right]-\mathrm{SP} \text { intracellular } \\
{\left[\mathrm{Ca}^{2+}\right] \text { fluorimetry }}\end{array}$ & 4.572 \\
\hline $\begin{array}{l}\text { Histamine receptor } \mathrm{H1} \text {, human, HEK histamine intracellu- } \\
\operatorname{lar}\left[\mathrm{Ca}^{2+}\right] \text { fluorimetry }\end{array}$ & 22.26 \\
\hline 5-HT 2 , human, HEK IP1 time-resolved fluorescence & 36.87 \\
\hline ERG human, $\mathrm{CHO}$ voltage ion flux electrophysiology & Efficacy $17.25 \%$ IC ${ }_{50} 11.1$ \\
\hline
\end{tabular}

VU0463271 was examined in a secondary pharmacology screen. List of targets that exhibited sensitivity to the compound in binding and functional assays. " Indicates an unidentified $\alpha 1$ subunit of the Cay L-type channels. 8-OH-DPAT, 8-hydroxy-2(di-n-propylamino)tetralin; BH-SP, Bolton Hunter-substance P; CGP12177, 4-[3-[(1,1dimethylethyl)amino]-2-hydroxypropoxy]-1, 3-dihydro-2H-benzimidazol-2-one; CGS 21680, 3-[4-[2-[[6-amino9-[(2R,3R,4S,5S)-5-(ethylcarbamoyl)-3,4-dihydroxy-oxolan-2-yl] purin-2-yl]amino]ethyl]phenyl]propanoic acid; ERG, Ether-a-go-go related gene; NBTI, S-(4-nitrobenzyl)-6-thioinosine; PPAR $\gamma$, peroxisome proliferator-activated receptor $\gamma_{;}$PK 11195, 1-(2-chlorophenyl)-N-methyl-N-(1-methylpropyl)-3-isoquinolinecarboxamide; U69593, $N$-methyl-2-phenyl- $N$-[(6R,8S,9S)-9-pyrrolidin-1-yl-1-oxaspiro[4.5]decan-8-yl] acetamide.

subtracted muscimol-activated or glycine-activated currents. The voltages from whole-cell experiments were corrected offline using a calculated liquid junction potential value $(16.3 \mathrm{mV})$ in Clampex (Molecular Devices). Transverse hippocampal slices $(400 \mu \mathrm{m})$ were immersed in ice-cold cutting solution containing the following (in $\mathrm{mm}$ ): $87 \mathrm{NaCl}, 2.5$ $\mathrm{KCl}, 0.5 \mathrm{CaCl}_{2}, 25 \mathrm{NaHCO}_{3}, 1.25 \mathrm{NaH}_{2} \mathrm{PO}_{4}, 7 \mathrm{MgCl}_{2}, 50$ sucrose, and 25 glucose (equilibrated with $95 \% \mathrm{O}_{2}$ and $5 \% \mathrm{CO}_{2}$ ). Slices recovered for $1 \mathrm{~h}$ in ACSF containing the following: (in $\mathrm{mm}$ ) $126 \mathrm{NaCl}, 26 \mathrm{NaHCO}_{3}, 1.5$ $\mathrm{NaH}_{2} \mathrm{PO}_{4}, 2.5 \mathrm{KCl}, 2 \mathrm{CaCl}_{2}, 2 \mathrm{MgCl}_{2}$, and 10 glucose at $34^{\circ} \mathrm{C}$. Electrodes filled with normal ACSF (1-5 M $\Omega$ resistance) and positioned in layer III of the medial entorhinal cortex were used to record epileptiform activity in normal ACSF with elevated $\mathrm{KCl}(5 \mathrm{~mm})$ and lacking $\mathrm{MgCl}_{2}$. Data were acquired at $10 \mathrm{kHz}$ with PowerLab hardware (ADInstruments) or an Axopatch 200B amplifier (Molecular Devices).

Intrahippocampal EEG recordings. Mice were implanted with differential depth recording electrodes fixed to a guide cannula (Plastics One) 1 week before experimentation. EEG recordings were acquired using $100 \times$ gain amplification, high-pass filtered at $1 \mathrm{~Hz}$. Epileptiform activity was measured in the dorsal hippocampus after unilateral intrahippocampal administration of $500 \mathrm{nl}$ of $100 \mu \mathrm{M}$ VU0463271 in freely moving unanesthetized mice. EEGs were assessed for ictal events and abnormal activity characterized by periods of rhythmic spiking lasting longer than $30 \mathrm{~s}$ (Lee and Maguire, 2013). Spectrum analysis was performed to assess changes in the power of the FFT. LabChart Pro software was used for data acquisition and analysis.

Statistics. Statistical analysis was performed using Prism 4 software (GraphPad Software). Paired $t$ tests (two-tailed) were used throughout except when indicated, and $p<0.05$ was considered significant. $I-V$ relationships were fit by linear regression analysis using GraphPad software. All data are reported as the mean \pm SEM.

\section{Results}

VU0463271 inhibited KCC2 function in HEK cells

We performed gramicidin perforated patch recordings in HEK cells transfected with glycine receptors and KCC2. These cells exhibited outward glycine-activated currents at a holding potential of $-30 \mathrm{mV}$ and basal $E_{\mathrm{Gly}}$ values of $-71 \pm 2 \mathrm{mV}$ ( $n=7$ cells; Fig. $1 A, B)$. A 5 min perfusion of VU0463271 $(10 \mu \mathrm{M})$ decreased the amplitude of glycine-activated currents (Fig. $1 A$ ), which was caused by a positive shift in $E_{\mathrm{Gly}}$ values to $-35 \pm 1 \mathrm{mV}(n=7, p=$ $0.0002)$, corresponding to a $\left[\mathrm{Cl}^{-}\right]_{\mathrm{i}}$ shift from $10.2 \pm 0.7$ to $40.3 \pm$ $1.6 \mathrm{~mm}$ (Fig. 1B). VU0463271 did not reduce the slope conductance of glycine-activated currents (data not shown). After a 5 min washout, $E_{\mathrm{Gly}}$ returned to basal values $(-63 \pm 2 \mathrm{mV}, n=7$, $p=0.0718)$.

Application of $100 \mathrm{~nm}$ VU0463271 on the same cells for $5 \mathrm{~min}$ increased $E_{\mathrm{Gly}}$ values to $-43 \pm 1 \mathrm{mV}$ and calculated $\left[\mathrm{Cl}^{-}\right]_{\mathrm{i}}$ to $28.7 \pm 1.3 \mathrm{~mm}$, which was significantly lower than values obtained in the presence of $10 \mu \mathrm{M}(n=7, p=0.0245$; Fig. $1 B)$. Washout of VU0463271 resulted in a rapid recovery of $E_{\mathrm{Gly}}$ to $-71 \pm 2 \mathrm{mV}(p=0.9602$, compared with basal levels $)$. Using the calculated $\left[\mathrm{Cl}^{-}\right]_{\mathrm{i}}$ values, the shift of $100 \mathrm{~nm}$ relative to $10 \mu \mathrm{M}$ VU0463271 was $68 \pm 4 \%$, which is similar to the relative efficacy of $100 \mathrm{~nm}$ VU0463271 obtained by $\mathrm{Rb}^{+}$flux assays (Delpire et al., 2012). In contrast, cells not transfected with KCC2 were insensitive to $10 \mu \mathrm{M}$ VU0463271 ( $E_{\mathrm{Gly}}$ values: $-24 \pm 1 \mathrm{mV}$ before, $-26 \pm 1 \mathrm{mV}$ after $5 \mathrm{~min}$ exposure, $n=7, p=0.3869$ ) but were sensitive to the NKCC1 inhibitor bumetanide $\left(10 \mu \mathrm{M} ; E_{\mathrm{Gly}}\right.$ values: $-21 \pm 1 \mathrm{mV}$ before, $-27 \pm 1 \mathrm{mV}$ after $5 \mathrm{~min}$ exposure, $n=$ $5, p=0.0059)$. To evaluate the selectivity of VU0463271 beyond its initial characterization, a secondary pharmacology screen was performed that identified several high-potency hits, including the mitochondrial translocator protein TSPO $\left(\mathrm{IC}_{50}\right.$ of $\sim 200 \mathrm{nM}$; Rupprecht et al., 2010) and the $\alpha 1 \mathrm{~B}$ adrenergic receptor $\left(\mathrm{IC}_{50}\right.$ of 350 nM; Pizzanelli et al., 2009; Table 1). Importantly, these proteins are not known to affect $\mathrm{Cl}^{-}$homeostasis. These data indicated that VU0463271 inhibited KCC2 function in HEK cells in a reversible and concentration-dependent manner.

\section{VU0463271 inhibited KCC2 function in cultured neurons}

We examined the effects of VU0463271 in cultured hippocampal neurons using the gramicidin perforated patch technique. We used the $\mathrm{GABA}_{\mathrm{A}}$ agonist muscimol $(5 \mu \mathrm{M})$ to measure $E_{\mathrm{GABA}}$ values, which was $-76 \pm 5 \mathrm{mV}(n=11)$ under basal conditions (Fig. 1C). A $5 \mathrm{~min}$ perfusion of $10 \mu \mathrm{M}$ VU0463271 converted hyperpolarizing muscimol responses into depolarizing potentials and shifted $E_{\mathrm{GABA}}$ values to $-36 \pm 2 \mathrm{mV}(n=11, p<0.0001)$, corresponding to a $\left[\mathrm{Cl}^{-}\right]_{\mathrm{i}}$ shift from $9.8 \pm 1.6$ to $39.1 \pm 2.6 \mathrm{~mm}$ (Fig. 1C,D). During washout of VU0463271, neurons reestablished hyperpolarizing muscimol responses and $E_{\mathrm{GABA}}$ values of $-80 \pm 5 \mathrm{mV}(p=0.2280$, compared with basal levels; Fig. $1 D)$. On separate neurons, a 5 min perfusion of $100 \mathrm{~nm} \mathrm{VU0463271}$ shifted $E_{\mathrm{GABA}}$ values from $-73 \pm 4$ to $-42 \pm 3 \mathrm{mV}(n=10, p=$ $0.0011)$, corresponding to a $\left[\mathrm{Cl}^{-}\right]_{\mathrm{i}}$ shift from $10.4 \pm 1.3$ to $32.4 \pm$ $4.4 \mathrm{~mm}$ (Fig. 1C). Washout of VU0463271 allowed a recovery of hyperpolarizing muscimol responses and $E_{\mathrm{GABA}}$ values of $-78 \pm$ $7 \mathrm{mV}(n=10, p=0.7707$, compared with basal levels). In addition, the effects of VU0463271 $(10 \mu \mathrm{M})$ were occluded in the presence of $10 \mathrm{~mm}\left[\mathrm{~K}^{+}\right]_{\mathrm{o}}\left(E_{\mathrm{GABA}}\right.$ in high $\left[\mathrm{K}^{+}\right]_{\mathrm{o}},-37 \pm 5 \mathrm{mV}$; $E_{\mathrm{GABA}}$ in high $\left[\mathrm{K}^{+}\right]_{\mathrm{o}}$ plus VU0463271, $-40 \pm 3 \mathrm{mV}, n=5, p=$ $0.4544)$.

To further characterize VU0463271, we performed whole-cell experiments on cultured neurons using recording pipettes containing $10 \mathrm{~mm} \mathrm{Cl}^{-}$. Basal $E_{\mathrm{GABA}}$ values $(-83 \pm 2 \mathrm{mV}, n=13)$ and the calculated $\left[\mathrm{Cl}^{-}\right]_{\mathrm{i}}(6.6 \pm 0.5 \mathrm{~mm})$ were below the predicted Nernst potential value of approximately $-72 \mathrm{mV}$ and the imposed pipette $\left[\mathrm{Cl}^{-}\right]$, indicating that these neurons expressed a persistent $\mathrm{Cl}^{-}$extrusion mechanism. Consistent with inhibition 


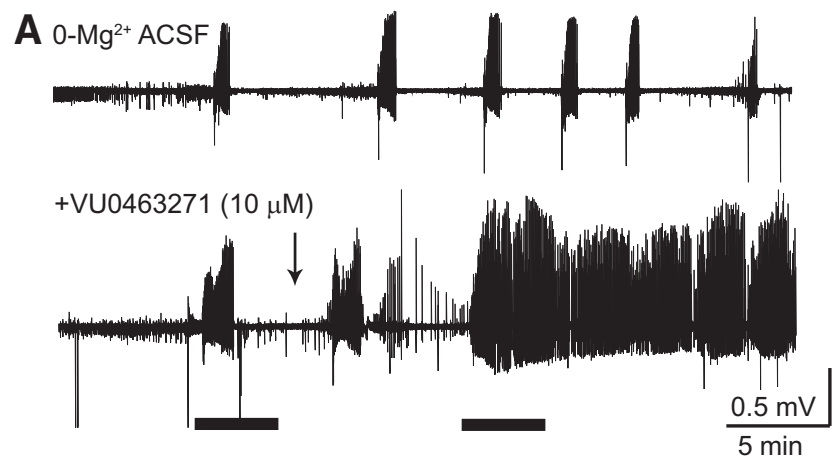

B

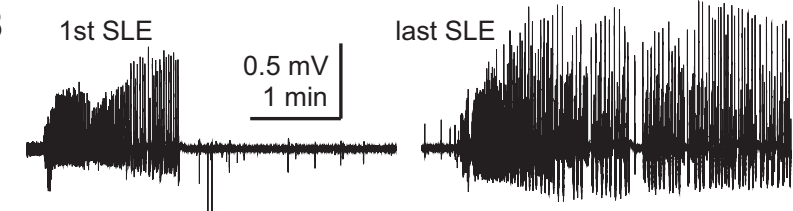

C

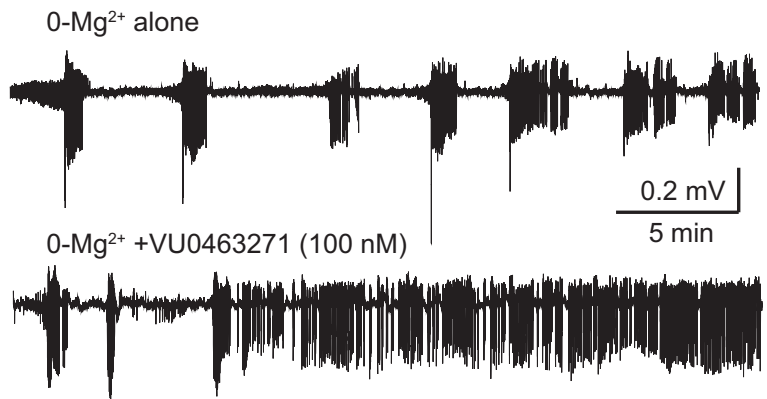

Figure 2. VU0463271 caused unremitting recurrent discharges in the low- $\mathrm{Mg}^{2+}$ model of epileptiform activity. $\boldsymbol{A}$, Representative traces of $0 \mathrm{Mg}^{2+}$-induced SLEs recorded from layer III of the medial entorhinal cortex in acutely prepared slices in the absence (top trace) and presence $(10 \mu \mathrm{M})$ of VU0463271. The arrow in the bottom trace indicates the onset of VU0463271 perfusion. $\boldsymbol{B}$, Highermagnification traces of the first and last SLEs from the bottom trace in $\boldsymbol{A}$ (black bars). Note that the last SLE did not terminate. C, Representative traces demonstrating the effect of VU0463271 (100 nM, preincubated for $15 \mathrm{~min}$ ) on $0 \mathrm{Mg}^{2+}$-induced epileptiform activity.

of KCC2, exposure to VU0463271 (10 $\mu \mathrm{M})$ rapidly and reversibly increased $E_{\mathrm{GABA}}$ to $-62 \pm 1 \mathrm{mV}$, corresponding to $\left[\mathrm{Cl}^{-}\right]_{\mathrm{i}}$ values of $14.3 \pm 0.5 \mathrm{~mm}(n=13, p<0.0001)$. The imposed $\mathrm{Cl}^{-}$load from the pipette revealed that KCC2 was completely inhibited within 2 min. In parallel, we examined VU0463271 on the resting membrane potential and input resistance, which were significantly increased from $-69.8 \pm 1.5$ to $-68.2 \pm 1.5 \mathrm{mV}(n=13$, $p=0.0002)$ and $149 \pm 16$ to $161 \pm 18 \mathrm{M} \Omega(p=0.0192)$. These changes in the membrane properties are consistent with decreased $\mathrm{Cl}^{-}$leak currents caused by elevated $\left[\mathrm{Cl}^{-}\right]_{\mathrm{i}}$.

The small resting membrane potential shift cannot account for the high $E_{\mathrm{GABA}}$ values obtained in the presence of VU0463271; therefore, we examined the two most likely sources of $\mathrm{Cl}^{-}$loading. Coapplication of VU0463271 and bumetanide (both $10 \mu \mathrm{M}$ ) caused a depolarizing $E_{\mathrm{GABA}}$ shift to $-39 \pm 2 \mathrm{mV}(n=8, p=$ 0.2937 , compared with VU0463271 alone, unpaired $t$ test), indicating that NKCC1 was not a major source in these cultured cells (Fig. $1 E, F)$. However, addition of TTX to this mixture reduced the driving force on $\mathrm{GABA}_{\mathrm{A}}$-mediated currents and caused a progressive hyperpolarizing $E_{\mathrm{GABA}}$ shift over $4 \mathrm{~min}$ to $-52 \pm 3 \mathrm{mV}$ ( $n=8, p=0.0002$, compared with VU0463271 plus bumetanide), indicating that activity-dependent depolarizations contributed a substantial portion of the $\mathrm{Cl}^{-}$load (Fig. 1 E, F; Buzsáki et al., 2007). In separate experiments, application of $10 \mu \mathrm{M}$ VU0463271 increased the number of spontaneous action potentials (APs) from $18 \pm 5$ to $78 \pm 26 \mathrm{AP} / \min (n=15, p=0.0330$;

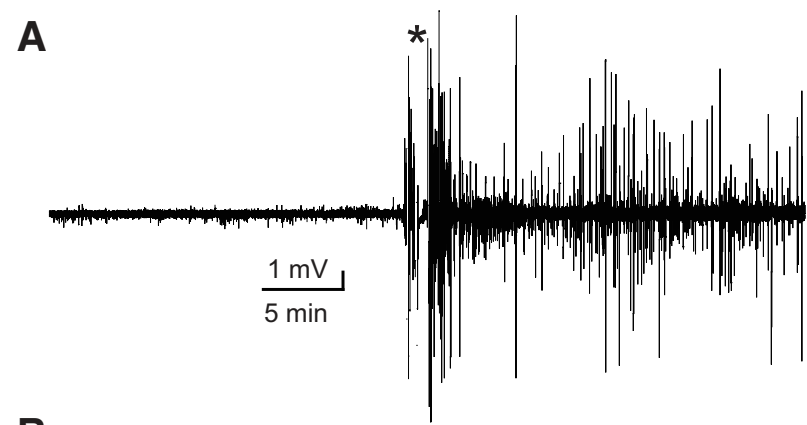

B
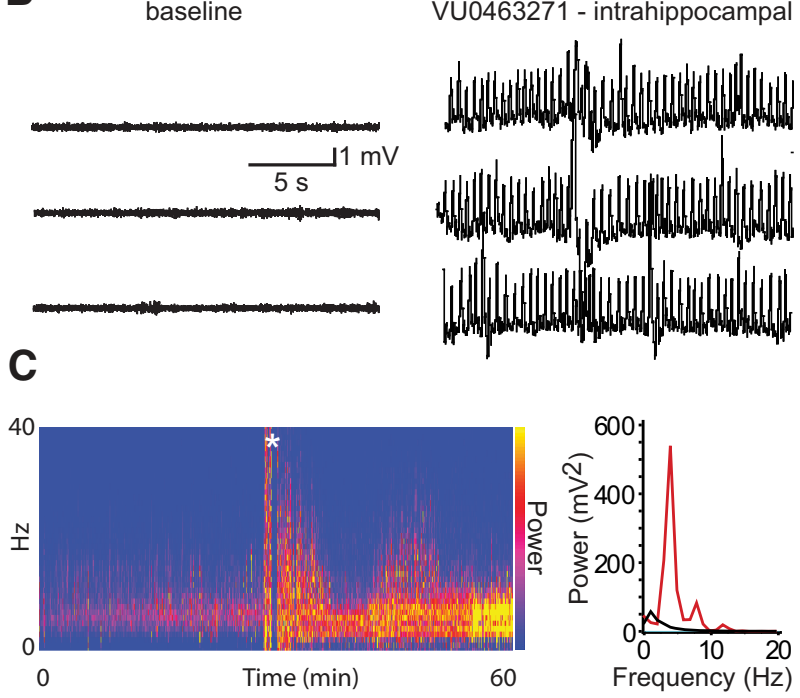

Figure 3. Intrahippocampal administration of VU0463271 caused epileptiform activity in vivo. A, Representative recording of EEG activity before and after microinfusion of $100 \mu \mathrm{m}$ VU0463271 (asterisk) into the hippocampus. B, An expanded trace of activity before and after microinfusion of VU0463271. C, Left, A representative spectrogram of the power of the EEG activity before and after VU0463271 microinfusion (asterisk). Right, The average power of the EEG activity demonstrates an increase in the low-frequency activity after VU0463271 microinfusion (red) compared with baseline (black).

Fig. 1G). Similarly, application of $100 \mathrm{~nm}$ VU0463271 increased the firing rate from $22 \pm 6$ to $83 \pm 23 \mathrm{AP} / \mathrm{min}(n=10, p=$ 0.0165). Together, these data indicated that VU0463271 impaired KCC2 function, resulting in increased network activity that exacerbated the initial $\mathrm{Cl}^{-}$extrusion deficit.

\section{VU0463271 caused epileptiform activity in hippocampal} slices and in vivo

Previous studies indicated that the nonselective KCC2 inhibitor furosemide blocked seizure-like events (SLEs) in the low- $\mathrm{Mg}^{2+}$ in vitro model of epilepsy (Hochman et al., 1995; Gutschmidt et al., 1999). Therefore, we tested whether VU0463271 had similar effects. Field recordings from layer III of the medial entorhinal cortex demonstrated that, during perfusion of $\mathrm{Mg}^{2+}$-free ACSF, repetitive SLEs appeared over the course of $120 \mathrm{~min}$ (Fig. 2A). SLEs were characterized by slow-wave deflections with superimposed high-frequency events, followed by an afterdischarge phase (Fig. 2A,B). After the development of the first SLE, addition of VU0463271 (10 $\mu \mathrm{M})$ quickly disrupted the pattern of SLEs transitioning to a persistent afterdischarge phase or recurrent epileptiform discharges in all slices tested ( $n=5$ slices; Fig. $2 A, B)$. We further examined SLEs in slices that were preincubated for 15 min with $100 \mathrm{~nm}$ VU0463271. Perfusion of $\mathrm{Mg}^{2+}$-free ACSF in the continued presence of VU0463271 caused a series of initial 
SLEs that transitioned to persistent recurrent discharges at $24 \pm 4$ min after $\mathrm{Mg}^{2+}$ washout in all slices tested ( $n=8$ slices; Fig. $2 C$ ). At the same time points, all control slices in $\mathrm{Mg}^{2+}$-free ACSF displayed SLEs but no recurrent discharges ( $n=9$ slices). These data indicated that selective inhibition of KCC2 resulted in unremitting epileptiform activity in brain slices exposed to low- $\mathrm{Mg}^{2+}$ conditions.

Because of the rapid metabolism of systemically administered VU0463271 (Delpire et al., 2012), we examined its effects on EEG activity after unilateral intrahippocampal administration. Microinfusion of VU0463271 (100 $\mu \mathrm{M}, 1 \mathrm{~min})$ resulted in immediate behavioral arrest that was associated with rhythmic spiking activity beginning $12 \pm 7 \mathrm{~s}$ after infusion, which lasted $23 \pm 10 \mathrm{~min}$ in duration ( $n=4$ mice; Fig. $3 A, B)$. A representative power spectra of EEG activity before and immediately after intrahippocampal administration revealed the occurrence of high-powered, lowfrequency $(1-16 \mathrm{~Hz})$, rhythmic epileptiform activity with a peak frequency of $3.9 \mathrm{~Hz}$ (Fig. 3C). Consistent with our slice recordings, our in vivo data revealed that KCC2 inhibition resulted in a persistent recurrent discharge pattern without ictal-like activity. These data indicated that inhibition of KCC2 in a small region of the hippocampus produced aberrant epileptiform activity.

\section{Discussion}

Our data demonstrated that selective pharmacological inhibition of KCC2 function affects neuronal activity in vitro, ex vivo, and in vivo. Although the nonselective KCC2 inhibitor furosemide has similar effects as VU0463271 on KCC2 function in cultured neurons and KCC2-expressing cell lines (Payne, 1997; Lee et al., 2011; Friedel et al., 2013), furosemide suppresses synchronized activity under epileptiform conditions in slices and in vivo (Ahmad et al., 1976; Hochman et al., 1995; Gutschmidt et al., 1999; Haglund and Hochman, 2005). Reviews of the literature led to the conclusions that the antiseizure efficacy of furosemide is caused by inhibition of NKCC1 (Hochman, 2012) and/or targets outside the CNS (Löscher et al., 2013). Our slice and whole animal experiments support these hypotheses, because selective inhibition of KCC2 in the hippocampus resulted in a rapid appearance of epileptiform activity.

It is well known that GABAergic interneurons can cause activity-dependent shifts of intracellular $\mathrm{Cl}^{-}$(Thompson and Gähwiler, 1989). Positive $E_{\mathrm{GABA}}$ shifts and the underlying $\mathrm{Cl}^{-}$ loads can occur even in the presence of intact KCC2 function, but our results demonstrated that cultured neurons could not return $E_{\mathrm{GABA}}$ back to baseline levels in the presence of the KCC2 inhibitor. Furthermore, in ACSF where bicarbonate is used as the buffer, $\mathrm{GABA}_{\mathrm{A}}$-mediated $\mathrm{HCO}^{-}$currents can directly depolarize neurons and push $\left[\mathrm{Cl}^{-}\right]_{\mathrm{i}}$ above equilibrium (Burg et al., 1998; Viitanen et al., 2010). Thus, the combination of $\mathrm{GABA}_{\mathrm{A}}$-mediated $\mathrm{Cl}^{-} / \mathrm{HCO}^{-}{ }^{-}$currents, direct membrane depolarization, and KCC2 inhibition can cause a protracted loss of $\mathrm{GABA}_{\mathrm{A}}$-mediated hyperpolarizing potentials.

Our results with VU0463271 demonstrated that inhibition of KCC2 throughout the slice converted the SLEs into persistent discharge activity that is analogous to status epilepticus (Dreier and Heinemann, 1991), which is characterized as a breakdown of the endogenous seizure termination mechanism (Engel, 2006). It is unclear from our results where this breakdown occurred. Importantly, elevations of intracellular $\mathrm{Cl}^{-}$occur in several slice models of epilepsy (Fujiwara-Tsukamoto et al., 2010; Ilie et al., 2012; Lillis et al., 2012). All of these studies indicated that the $\left[\mathrm{Cl}^{-}\right]_{\mathrm{i}}$ of hippocampal principle cells surges to high levels during SLE onset and remains high until after spontaneous SLE termi- nation. However, it is not known whether $\left[\mathrm{Cl}^{-}\right]_{\mathrm{i}}$ levels rise within the local population of interneurons that are also subjected to GABAergic control. Thus, the effects of VU0463271 on SLE termination could be attributable to the impaired $\mathrm{Cl}^{-}$extrusion mechanism in the principle cells and/or in the upstream interneurons that normally drive the clonic afterdischarge phase of SLEs (Ellender et al., 2014). Our data on KCC2 function is consistent with theoretical models that predicted that an impaired $\mathrm{Cl}^{-}$extrusion mechanism would prolong SLEs (Krishnan and Bazhenov, 2011).

Given the large amount of data supporting the critical role of KCC2 in affecting $\mathrm{Cl}^{-}$homeostasis and the exclusive role played by synaptic $\mathrm{Cl}^{-}$channels in nervous systems, our results are somewhat unsurprising. However, the influence of KCC2 ion cotransport could not be elucidated before because of its transporter-independent properties and the previous lack of selective KCC2 inhibitors (Delpire et al., 2012). Here we have demonstrated that the selective KCC2 inhibitor VU0463271 can be used in cell-based assays, in brain slices under active conditions, and in vivo for additional exploration of the role of KCC2 during seizures.

\section{References}

Ahmad S, Clarke L, Hewett AJ, Richens A (1976) Controlled trial of frusemide as an antiepileptic drug in focal epilepsy. Br J Clin Pharmacol 3:621-625. CrossRef Medline

Alexander SP, Mathie A, Peters JA (2011) Guide to receptors and channels (GRAC), Ed 5. Br J Pharmacol 164 [Suppl 1]:S1-S324. CrossRef

Ben-Ari Y, Cherubini E, Corradetti R, Gaiarsa JL (1989) Giant synaptic potentials in immature rat CA3 hippocampal neurones. J Physiol 416:303325. CrossRef Medline

Burg M, Heinemann U, Schmitz D (1998) Neuroactive steroids induce GABA(A) receptor-mediated depolarizing postsynaptic potentials in hippocampal CA1 pyramidal cells of the rat. Eur J Neurosci 10:2880-2886. CrossRef Medline

Buzsáki G, Kaila K, Raichle M (2007) Inhibition and brain work. Neuron 56:771-783. CrossRef Medline

Deeb TZ, Nakamura Y, Frost GD, Davies PA, Moss SJ (2013) Disrupted $\mathrm{Cl}(-)$ homeostasis contributes to reductions in the inhibitory efficacy of diazepam during hyperexcited states. Eur J Neurosci 38:2453-2467. CrossRef Medline

Delpire E, Baranczak A, Waterson AG, Kim K, Kett N, Morrison RD, Daniels JS, Weaver CD, Lindsley CW (2012) Further optimization of the K-Cl cotransporter KCC2 antagonist ML077: development of a highly selective and more potent in vitro probe. Bioorg Med Chem Lett 22:4532-4535. CrossRef Medline

Dreier JP, Heinemann U (1991) Regional and time dependent variations of low $\mathrm{Mg} 2+$ induced epileptiform activity in rat temporal cortex slices. Exp Brain Res 87:581-596. Medline

Ellender TJ, Raimondo JV, Irkle A, Lamsa KP, Akerman CJ (2014) Excitatory effects of parvalbumin-expressing interneurons maintain hippocampal epileptiform activity via synchronous afterdischarges. J Neurosci 34:15208-15222. CrossRef Medline

Engel J Jr (2006) Report of the ILAE classification core group. Epilepsia 47:1558-1568. CrossRef Medline

Fiumelli H, Briner A, Puskarjov M, Blaesse P, Belem BJ, Dayer AG, Kaila K, Martin JL, Vutskits L (2013) An ion transport-independent role for the cation-chloride cotransporter KCC2 in dendritic spinogenesis in vivo. Cereb Cortex 23:378-388. CrossRef Medline

Freund TF, Buzsáki G (1996) Interneurons of the hippocampus. Hippocampus 6:347-470. CrossRef Medline

Friedel P, Bregestovski P, Medina I (2013) Improved method for efficient imaging of intracellular $\mathrm{Cl}(-)$ with $\mathrm{Cl}$-sensor using conventional fluorescence setup. Front Mol Neurosci 6:7. CrossRef Medline

Fujiwara-Tsukamoto $\mathrm{Y}$, Isomura $\mathrm{Y}$, Imanishi M, Ninomiya T, Tsukada M, Yanagawa Y, Fukai T, Takada M (2010) Prototypic seizure activity driven by mature hippocampal fast-spiking interneurons. J Neurosci 30: 13679-13689. CrossRef Medline

Gauvain G, Chamma I, Chevy Q, Cabezas C, Irinopoulou T, Bodrug N, 
Carnaud M, Lévi S, Poncer JC (2011) The neuronal K-Cl cotransporter KCC2 influences postsynaptic AMPA receptor content and lateral diffusion in dendritic spines. Proc Natl Acad Sci U S A 108:15474-15479. CrossRef Medline

Gutschmidt KU, Stenkamp K, Buchheim K, Heinemann U, Meierkord H (1999) Anticonvulsant actions of furosemide in vitro. Neuroscience 91: 1471-1481. CrossRef Medline

Haglund MM, Hochman DW (2005) Furosemide and mannitol suppression of epileptic activity in the human brain. J Neurophysiol 94:907-918. CrossRef Medline

Hochman DW (2012) The extracellular space and epileptic activity in the adult brain: explaining the antiepileptic effects of furosemide and bumetanide. Epilepsia 53 [Suppl 1]:18-25. CrossRef

Hochman DW, Baraban SC, Owens JW, Schwartzkroin PA (1995) Dissociation of synchronization and excitability in furosemide blockade of epileptiform activity. Science 270:99-102. CrossRef Medline

Hübner CA, Stein V, Hermans-Borgmeyer I, Meyer T, Ballanyi K, Jentsch TJ (2001) Disruption of KCC2 reveals an essential role of K-Cl cotransport already in early synaptic inhibition. Neuron 30:515-524. CrossRef Medline

Ilie A, Raimondo JV, Akerman CJ (2012) Adenosine release during seizures attenuates GABAA receptor-mediated depolarization. J Neurosci 32: 5321-5332. CrossRef Medline

Isaacson JS, Scanziani M (2011) How inhibition shapes cortical activity. Neuron 72:231-243. CrossRef Medline

Jarolimek W, Brunner H, Lewen A, Misgeld U (1996) Role of chloridehomeostasis in the inhibitory control of neuronal network oscillators. J Neurophysiol 75:2654-2657. Medline

Krishnan GP, Bazhenov M (2011) Ionic dynamics mediate spontaneous termination of seizures and postictal depression state. J Neurosci 31:88708882. CrossRef Medline

Lee HH, Deeb TZ, Walker JA, Davies PA, Moss SJ (2011) NMDA receptor activity downregulates KCC2 resulting in depolarizing GABAA receptormediated currents. Nat Neurosci 14:736-743. CrossRef Medline

Lee V, Maguire J (2013) Impact of inhibitory constraint of interneurons on neuronal excitability. J Neurophysiol 110:2520-2535. CrossRef Medline

Li H, Khirug S, Cai C, Ludwig A, Blaesse P, Kolikova J, Afzalov R, Coleman SK, Lauri S, Airaksinen MS, Keinänen K, Khiroug L, Saarma M, Kaila K, Rivera C (2007) KCC2 interacts with the dendritic cytoskeleton to promote spine development. Neuron 56:1019-1033. CrossRef Medline

Lillis KP, Kramer MA, Mertz J, Staley KJ, White JA (2012) Pyramidal cells accumulate chloride at seizure onset. Neurobiol Dis 47:358-366. CrossRef Medline

Löscher W, Puskarjov M, Kaila K (2013) Cation-chloride cotransporters NKCC1 and KCC2 as potential targets for novel antiepileptic and antiepileptogenic treatments. Neuropharmacology 69:62-74. CrossRef Medline

Mahadevan V, Pressey JC, Acton BA, Uvarov P, Huang MY, Chevrier J, Puchalski A, Li CM, Ivakine EA, Airaksinen MS, Delpire E, McInnes RR, Woodin MA (2014) Kainate receptors coexist in a functional complex with KCC2 and regulate chloride homeostasis in hippocampal neurons. Cell Rep 7:1762-1770. CrossRef Medline

Payne JA (1997) Functional characterization of the neuronal-specific K-Cl cotransporter: implications for $[\mathrm{K}+] \mathrm{o}$ regulation. Am J Physiol 273: C1516-C1525. Medline

Pizzanelli C, Lazzeri G, Fulceri F, Giorgi FS, Pasquali L, Cifelli G, Murri L, Fornai F (2009) Lack of alpha 1b-adrenergic receptor protects against epileptic seizures. Epilepsia 50 [Suppl 1]:59-64.

Rivera C, Voipio J, Payne JA, Ruusuvuori E, Lahtinen H, Lamsa K, Pirvola U, Saarma M, Kaila K (1999) The K+/Cl- co-transporter KCC2 renders GABA hyperpolarizing during neuronal maturation. Nature 397:251255. CrossRef Medline

Rupprecht R, Papadopoulos V, Rammes G, Baghai TC, Fan J, Akula N, Groyer G, Adams D, Schumacher M (2010) Translocator protein (18 $\mathrm{kDa})(\mathrm{TSPO})$ as a therapeutic target for neurological and psychiatric disorders. Nat Rev Drug Discov 9:971-988. CrossRef Medline

Schwartzkroin PA (1981) Development of rabbit hippocampus: physiology. Brain Res 254:469-486. Medline

Thompson SM, Gähwiler BH (1989) Activity-dependent disinhibition. II. Effects of extracellular potassium, furosemide, and membrane potential on ECl- in hippocampal CA3 neurons. J Neurophysiol 61:512-523. Medline

Uvarov P, Ludwig A, Markkanen M, Pruunsild P, Kaila K, Delpire E, Timmusk T, Rivera C, Airaksinen MS (2007) A novel N-terminal isoform of the neuron-specific K-Cl cotransporter KCC2. J Biol Chem 282:30570 30576. CrossRef Medline

Viitanen T, Ruusuvuori E, Kaila K, Voipio J (2010) The K+-Cl cotransporter KCC2 promotes GABAergic excitation in the mature rat hippocampus. J Physiol 588:1527-1540. CrossRef Medline

Woo NS, Lu J, England R, McClellan R, Dufour S, Mount DB, Deutch AY, Lovinger DM, Delpire E (2002) Hyperexcitability and epilepsy associated with disruption of the mouse neuronal-specific $\mathrm{K}-\mathrm{Cl}$ cotransporter gene. Hippocampus 12:258-268. CrossRef Medline 